\section{Hungarian universities}

\section{Degrees of difference}

HUNGARY'S system of postgraduate education has been reformed. Last month, the Presidential Council approved a law establishing a new scientific degree, that of "university doctor", ranking below the existing degrees of "candidate" and "doctor of sciences". Ironically, the change has been urged by academics as a way of making young scientists less diploma-orientated.

Under the old system, young scholars could not even begin work on their candidate dissertation until they had published several pieces of research. One result is that of Hungary's 50,000 "scientific workers" (including social scientists and humanists), only some 20 per cent have a higher degree. Under the new system, however, people will be able to apply for a special "university fellowship" immediately after taking their first degrees. Fellowships will be awarded on the basis of an examination that will include a foreign language and a "philosophicalideological", section as well as the applicant's special subject, and will carry a stipend of 5,200 forints a month, comparable with a university lecturer's salary of 5,800 forints.

The completed dissertation will be defended after three years before a committee of both academy and university specialists. Those submitting dissertations of a sufficiently high standard will be awarded a candidate's degree, while the less outstanding but still competent will receive the lower degree of "university doctor"

Although the new procedure will become law only in September 1984, the first batch of applications was accepted last December, and 390 fellowships have already been awarded (out of 520 applicants). These include not only 1982 graduates but also several young scientists who did not yet have the necessary publications to start a candidate's dissertation under the old system. A number of young physicians were also attracted to the new fellowships, as a means of switching from practical medicine to medical research.

Although it is too soon for the scheme to be assessed, a preliminary report presented to the presidium of the Academy of Sciences (which has overall responsibility for the operation of the scheme) suggests that the initial selection procedures are working satisfactorily, with 50 per cent of the new fellows accommodated in university research facilities and the rest in academy institutes. The chance of a higher degree at an earlier age may help to overcome the dissatisfaction caused by the extremely low starting salaries of young graduates, often below those of a manual worker of the same age.

Vera Rich

\title{
European Science Foundation
} Fund of ideas but no funds

\section{Strasbourg}

AMBITION and timidity again collided at this year's general assembly of the European Science Foundation, Europe's unique blend of grant-making organization and learned academy whose members appoint themselves. Yet paradoxically, the foundation seems in good spirits.

Last week, the assembly was told of a plan to mount an infrared telescope in a converted civil aircraft (to fashion an "astroplane") and of the lingering hope (after four years of frustration) that European governments will find a way to build a super electron storage ring for generating synchrotron radiation. But the foundation also relinquished direct responsibility for one of its successes so far - a fellowship and training programme in neurophysiology - and was told clearly that it would lose all credibility with social scientists if it could not raise the funds needed for a study begun three years ago of language learning among adult immigrants.

The foundation's difficulties mostly arise because it is an impresario for research, not a research organization as such. Of next year's budget of FF8.95 million ( $£ 734,000$ ) (approved last week), close on 90 per cent will be spent on administration - always vulnerable, never popular. And although the foundation will probably handle as much again on account of its research projects (quaintly called "additional activities"), that part of the budget is contributed only by those members willing to support individual projects.

Whence the row about language learning. The objective is to understand how adult immigrants - Bengalis and Italians in Britain, Finns in Sweden, Turks in Germany and Moroccans in France, for example - acquire the language of their host environment (if at all). The project fits in well with others of the social science projects, including a major study of intramigration due to be completed next year. Unfortunately, when the foundation willed the end, it was constitutionally incapable of willing the means.

Professor W.J.M. Levelt, director of the Max-Planck-Institut für Psycholinguistik at Nijmegen (Netherlands), which coordinates the project, said last week that work was well under way on the core of the project - a scheme to assess the linguistic progress of a sample of more than 200 guest workers in five different countries. Yet last year (1982), the foundation had wrung only FF1.4 million from its members towards the total cost of FF2.4 million. The Max-Planck-Gesellschaft had bridged the gap, paying the salaries of four research workers and even suppling the five research teams with a minicomputer for use

\section{in data analysis.}

But this cannot carry on, and is in any case "not acceptable", Levelt said. "You cannot vote year after year to approve the budget and then fail to accept the consequences of your joint decision." And if the further FF8 million that will be needed (over three years) had not been promised by the end of the year, activities would have to be curtailed and "the reputation of the European Science Foundation with social scientists will be in question". Most members looked at their feet, but the Finnish Academy and Norway promised to look at the question urgently, and Britain and France said they would consider increasing their contributions.

These are the hazards ahead of the astroplane. According to Professor C. de Jager of the Space Research Laboratory at Utrecht (Netherlands), the objective is to modify either an Airbus or a Canadian Challenger aircraft to carry $2-\mathrm{m}$ and $1-\mathrm{m}$ infrared telescopes respectively. Total costs, including 300 hours of operations a year over the decade, would amount to FF350 million for the Airbus and FF150 million for the Challenger. De Jager argued that the project would be complementary to satellite and ground-based observations, but that it would put balloons out of the infrared business. It seems to be understood that France and Germany will decide between them which option, if any, flies.

The European synchrotron radiation project is in much the same position. Refinement has continued of the design for a 5-GeV storage ring capable of generating synchrotron radiation at a wavelength of $0.1 \AA$. There are now several potential sites all over Europe, but none of the host governments has as yet offered a sufficiently large share to get the project started. Meanwhile, the planners are worried by the proposal of Stanford University in California to build a $6-\mathrm{GeV}$ storage ring for the same purpose. The general opinion is that a decision must be made by next year or the European project must be abandoned.

Technically, this is what has happened to the European Training Programme in Brain and Behaviour Research, which organizes training courses and provides student travel grants in fields related to neurobiology. Having decided a year ago that the programme should be left to its own devices so as to free itself for new initiatives, the foundation was this year faced with a demand from the sponsors that it should continue to administer the scheme, which will henceforth be designated an "associated programme".

Professor H. Curien, the foundation's president (who is head of the Centre National d'Etudes Spatiales in Paris), explained that the underlying objective is to let successful projects make their own 
way in the world so as to concentrate the foundation's energies on new projects. The Max-Planck-Gesellschaft seems to have been especially influential in this decision but observers (not all journalists) wonder why the foundation should discard the feathers in its cap, especially when its members are unready to turn their enthusiasm for innovations into cash.

None of this seems to have prevented the assembly last week from pushing ahead with other plans. Byzantine and Chinese studies flourish, and the deep seismic sounding project known as the European Geotraverse has begun well. (There are even plans to interest the Soviet Union in the inclusion of the Kola Peninsula.) The foundation is also helping geophysicists to press their claims for a fair crack of the whip in the launching of European satellites, its long-standing interest in polymer science has led to the planned formation of a European Polymer Foundation, and the foundation programme of fellowships in toxicology has spawned an agreement with the European Commission for a study of the toxicology of chlorophenol chloropropenes designed to provide Brussels with a scientific basis for regulation, and intended by both parties as a proving ground for Community regulations.

The formation of a consortium to allow the foundation's smaller member states to take part in the continuation of the US Deep Sea Drilling Project due to begin next October is more of a scramble. Professor $R$. van Lieshout, director of the Netherlands science research council (ZWO) and organizer of the consortium, explained that the rush stems from the late decision on the future of the deep-sea drilling in the United States. But now "the train as already left the station".

There seems no prospect that the smaller members of the foundation will be able to raise the $\$ 2.5$ million a year required of full members, so that hopes turn on whether Britain will opt for full participation (a decision still to be made by the UK Natural Environment Research Council), as France and West Germany have already done. One parsimonious solution canvassed last week is that the smaller members might club together to pay the $\$ 200,000$ needed for the first year's membership, thus influencing the programme, but then decide to pull out. Final bids will be disclosed at a meeting in Zurich early in December.

For the rest, the assembly approved the launching of a project on forest ecosystems after (and in spite of) an impassioned speech by Professor W. Bossard, director of the Swiss Federal Institute of Forestry Research, threatening catastrophe for alpine valleys from avalanches and soil erosion if forest die-back were allowed to continue. The assembly also elected Professor van Lieshout and Professor T.D. Spearman (Trinity College, Dublin) as vice-presidents for the next three years.

John Maddox

\section{UK research staff Too many dead-end jobs?}

THE conditions of employment of British university research workers, many of whom are engaged on short-term contracts, represent the "unacceptable face of the high-tech revolution", a meeting of the Association of University Teachers (AUT) was told last week. Mr John Akker, deputy general secretary of the association, said that researchers' terms and conditions of employment were more like those of farm workers than of key workers in a vital industry.

AUT estimates there are 12,000 research staff employed in the universities, including those in research council units. Their contracts are normally attached to particular projects and may last anything from 3 months to 5 years. Almost all contract researchers, according to AUT, are required as a condition of their employment to sign a waiver clause denying them the right to claim unfair dismissal or to seek a redundancy payment. Dr B. Salter, who chaired an AUT advisory group on the subject, says that this clause contravenes the spirit of the relevant legislation, which was intended to apply to wellpaid short-term contracts. Researchers are paid less than lecturers and advance more slowly.

Because conditions of service and opportunities for advancement are unattractive, few contract researchers stay for long: in 1980,81 per cent had been researching for less than 5 years, although their academic qualifications were similar to or better than those of lecturers. Mr Akker last week described the treatment of researchers as a "wasteful and gross exploitation of talent". He said that the Prime Minister should examine the problem urgently if she wishes to increase output from science and technology.

The meeting, attended by 90 delegates representing all of Britain's universities, formally established a National Committee of Contract Researchers. The committee will hold local meetings throughout the country and will seek meetings with the University Grants Committee, the Committee of Vice-Chancellors and Principals and research councils, as well as government. AUT intends to make full use of legal sanctions where these are applicable and may consider demonstrative action.

The main aim is to establish a recognized career structure. AUT will ask universities to consider the establishment of "bridging pools" to pay researchers between projects, funded by means of a surcharge on research contracts. But AUT also wants to see other improvements in researchers' terms of service.

It was pointed out last week that many lecturers, on accepting early retirement, receive golden handshakes of $£ 20,000$ or more. A researcher of the same age would receive nothing.
Dr Salter, who is now a member of the contract researchers' committee, is under no illusions about the difficulty of the task AUT faces. One problem is that responsibilities are fragmented: most researchers are paid by universities, which in turn receive grants from research councils. Neither will tackle the problem without the other, says Salter. Another difficulty is that a young research population is often thought to be a good source of fresh ideas. Salter dismisses this notion, and argues that the same might be said of any profession.

Tim Beardsley

\section{Developing academy}

Professor Abdus Salam, the Pakistani physicist and champion of Third World scientists, is to be president of a "ThirdWord academy" of leading scientists in and from the developing world, it was announced last Friday at a ceremony in Trieste, Italy. The academy - which, says Salam, "will be happy to advise governments and other bodies" on matters of science and development - begins with 25 full fellows, two of them Nobel Prize winners, chosen from the existing fellowships of prestigious academies including the US National Academy of Sciences, and 14

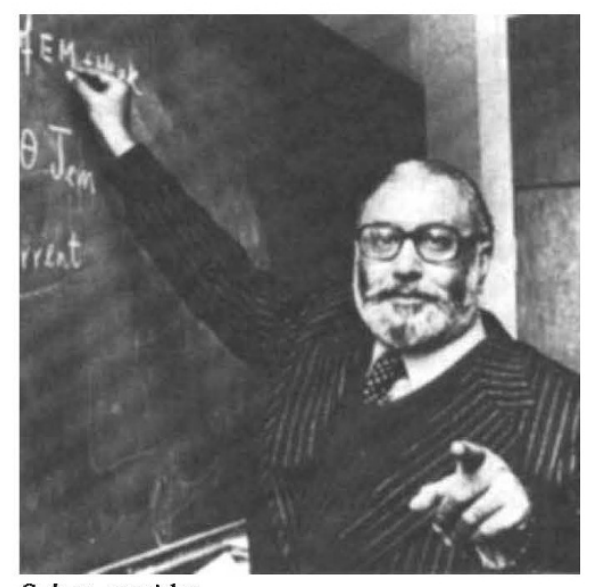

\section{Salam presides}

associate fellows. The associates are exnationals of developing countries now working in the West.

The academy will have four main roles, Salam said last week: to support "good men' in developing countries; to advise; to publish a newsletter on scientific issues in the Third World (to be edited in Caracas); and to promote "South-South" collaboration in science.

The academy will be "a collection of individuals", and thus a totally different exercise from the UN University, which Salam condemns as too bureaucratic. However, the new academy has as yet no budget. Salam sees himself doing a lot of the planning and writing of letters. The money will come, he says. Robert Walgate 